\title{
Condensed milk storage and evaporation affect the flavor of nonfat dry milk ${ }^{1}$
}

\author{
Curtis W. Park and MaryAnne Drake ${ }^{2}$ \\ Department of Food, Bioprocessing, and Nutrition Sciences, Southeast Dairy Foods Research Center, North Carolina State University, \\ Raleigh 27695
}

\begin{abstract}
Unit operations in nonfat dry milk (NFDM) manufacture influence sensory properties, and consequently, its use and acceptance in ingredient applications. Condensed skim milk may be stored at refrigeration temperatures for extended periods before spray drying due to shipping or lack of drying capacity. Currently, NFDM processors have 2 options for milk concentration up to $30 \%$ solids: evaporation (E) or reverse osmosis (RO). The objective of this study was to determine the effect of condensed milk storage and milk concentration method ( $\mathrm{E}$ vs. RO) on the flavor of NFDM and investigate mechanisms behind flavor differences. For experiment 1, skim milk was pasteurized and concentrated to $30 \%$ solids by $\mathrm{E}$ or RO and then either stored for $24 \mathrm{~h}$ at $4^{\circ} \mathrm{C}$ or concentrated to $50 \%$ solids by $\mathrm{E}$ and spray dried immediately. To investigate mechanisms behind the results from experiment 1 , experiment 2 was constructed. In experiment 2, pasteurized skim milk was subjected to 1 of 4 treatments: control (no $\mathrm{E}$ ), heated in the evaporator without vacuum, E concentration to $30 \%$ solids, or E concentration to $40 \%$ solids. The milks were then diluted to the same solids content and evaluated. Volatile compounds were also measured during concentration in the vapor separator of the evaporator. Sensory properties were evaluated by descriptive sensory analysis and instrumental volatile compound analysis was conducted to evaluate volatile compounds. Interaction effects between storage and method of concentration were investigated. In experiment 1, E decreased sweet aromatic flavor and many characteristic milk flavor compounds and increased cardboard and cooked flavors in NFDM compared with RO. Liquid storage increased cardboard flavor and hexanal and octanal and decreased sweet aromatic flavors and vanillin concentration. Results from experi-
\end{abstract}

\footnotetext{
Received May 30, 2016.

Accepted August 23, 2016.

${ }^{1}$ Use of names, names of ingredients, and identification of specific models of equipment is for scientific clarity and does not constitute any endorsement of product by authors, North Carolina State University, or the Southeast Dairy Foods Research Center.

${ }^{2}$ Corresponding author: mdrake@ncsu.edu
}

ment 2 indicated that the characteristic milk flavors and their associated volatile compounds were removed by the vapor separator in the evaporator due to the heat and vacuum applied during concentration. These results demonstrate that off-flavors are significantly reduced when $\mathrm{RO}$ is used in place of $\mathrm{E}$ and storage of condensed milk is avoided.

Key words: nonfat dry milk, unit operations, flavor

\section{INTRODUCTION}

Dried milk powders are widely used in the food industry. In 2014, approximately 970,000 t of nonfat dry milk (NFDM) and skim milk powder (SMP) was produced in the United States (USDA, 2015). Both SMP and NFDM must have $<1.5 \%$ fat, $<5.0 \%$ moisture, and $>34 \%$ protein (ADPI, 2015). Skim milk powder differs from NFDM in that milk permeate, milk retentate, or lactose can be added to adjust the protein content in SMP. As such, all NFDM can be called SMP but not all SMP are NFDM. The SMP and NFDM are expected to taste like fluid skim milk. Nonfat dry milk and SMP are used in the food industry to alter texture and flavor of ingredient applications. Flavor is a critical characteristic of milk powders for consumer acceptance of their ingredient applications (Caudle et al., 2005; Isleten and Karagul-Yuceer, 2006; Lloyd et al., 2009a,b).

Skim milk powders are expected to have a flavor similar to fluid skim milk, but off-flavors are often present. These off-flavors can be due to lipid oxidation, Maillard browning, enzymatic-induced changes, or microbial growth. Many studies have documented off-flavors that develop due to unit operations during the manufacture and storage of whole milk powder and NFDM (Karagul-Yuceer et al., 2001, 2002; Drake et al., 2003, 2007; Lloyd et al., 2009a). Milk-like flavors in NFDM include sweet aromatic and cooked, and offflavors can include cardboard, potato/brothy, cereal, and animal/wet dog (Drake et al., 2003). The sweet aromatic flavor has been attributed to lactones, vanillin, and free fatty acids (Karagul-Yuceer et al., 2001; Karagul-Yuceer et al., 2002; Shiratsuchi et al., 1995). Off-flavors in NFDM are caused by a variety of aldehydes, ketones, alcohols, and free fatty acids, primar- 
ily lipid oxidation compounds (Karagul-Yuceer et al., 2002; Drake et al., 2007).

Typical unit operations in NFDM manufacture include heat treatment, vacuum evaporation (E), and spray drying. Evaporation is performed with a falling film evaporator where water is boiled under vacuum to increase the solids content of the skim milk up to $50 \%$ TS before spray drying (Oldfield et al., 2005; Drake et al., 2007). Stapelfeldt et al. (1997) demonstrated that heat treatment significantly affected oxidation rate during storage of whole milk powder. Higher heat treatments decreased the amount of free radicals during storage due to exposed sulfhydryl groups on the whey proteins, allowing them to scavenge the free radicals. In addition, heat treatment temperature during pasteurization significantly affected whey protein denaturation, whereas evaporation and spray drying temperatures had little effect (Oldfield et al., 2005). Heat treatment also influenced the functional properties of NFDM in a set yogurt (Augustin et al., 1999). Spray-drying temperatures did alter the surface composition of SMP and whole milk powder and their functional properties (Nijdam and Langrish, 2006; Kim et al., 2009). Evaporation and spray drying significantly alter the flavor of SMP (Drake et al., 2007).

The use of reverse osmosis (RO) membranes can also remove water from skim milk up to $30 \%$ TS, replacing a portion of the E. Because the RO membranes do not require heating like $\mathrm{E}$, they can provide a significant reduction in energy costs (Stabile, 1983). Condensed skim milk ( $<36 \%$ solids) is often stored for extended periods of time due to shipping from one facility to another or inadequate spray-drying capacities of the manufacturing facility. Condensed skim milk is also widely used as an ingredient in various dairy products. Drake et al. (2007) observed that when evaporated skim milk ( $50 \%$ solids) was diluted to $9 \% \mathrm{SNF}$, cooked and sweet aromatic flavor intensities were decreased compared with rehydrated spray-dried NFDM. These authors did not investigate the cause of the loss of flavor and how evaporation affects the resulting milk powder flavor. To do so, 2 different methods of concentration of skim milk need to be investigated. The objective of this study was to determine the effect of condensed milk storage and method of concentration ( $\mathrm{RO}$ vs. E) on the flavor of the resulting NFDM and investigate a possible mechanism for the observed effects.

\section{MATERIALS AND METHODS}

\section{NFDM Production}

Experiment 1. Raw bovine skim milk (390 kg) was obtained from the North Carolina State University

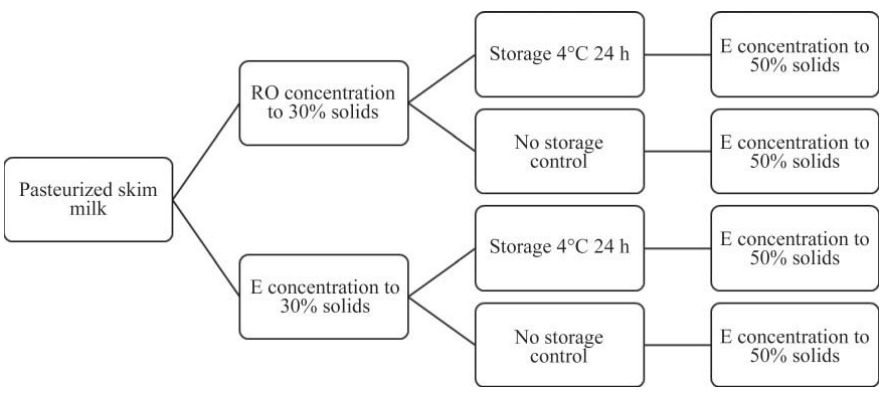

Figure 1. Flow diagram of nonfat dry milk (NFDM) production (experiment 1 ). The entire experiment was replicated 3 times. $\mathrm{RO}=$ reverse osmosis; $\mathrm{E}=$ evaporation.

Dairy Research and Education Unit. The skim milk was HTST pasteurized at $73^{\circ} \mathrm{C}$ for $16 \mathrm{~s}$ with a plate heat exchanger (model T4 RGS-16/2, SPX Flow Technology, Greensboro, NC). The milk was cooled to $4^{\circ} \mathrm{C}$ and stored in a bulk tank. Half of the skim milk was concentrated to $30 \%$ solids (wt/wt) by $\mathrm{RO}$ and the other half by E. Condensed milks were further split in 2 treatments: $4^{\circ} \mathrm{C}$ storage for $24 \mathrm{~h}$ or a no storage control. Prior to spray drying, the condensed milks were further concentrated to $50 \%$ solids by E. A diagram of the experimental design is shown in Figure 1.

Evaporation was carried out using a single effect pilot-scale falling film evaporator. For concentration of skim milk to $30 \%$ solids, the milk was pre-heated to $50^{\circ} \mathrm{C}$ before entering the calandria. The calandria temperature was $71^{\circ} \mathrm{C}$ with a vacuum of $74.5 \mathrm{kPa}$. Upon exiting the evaporator, the condensed milk was cooled through a tubular heat exchanger to $10^{\circ} \mathrm{C}$. The condensed milk was then cooled to $4^{\circ} \mathrm{C}$ and either placed in storage for $24 \mathrm{~h}$ or collected for further concentration. When evaporating the condensed milk (30\% solids) to $50 \%$ solids, the calandria temperature was $60^{\circ} \mathrm{C}$ and the vacuum was $81 \mathrm{kPa}$. The $50 \%$ solids condensed milk was $50^{\circ} \mathrm{C}$ upon exiting the evaporator and was immediately spray dried.

The RO was performed using 2 spiral-wound RO membrane elements (TRO 3838, Toray Membrane USA Inc., Poway, CA). The skim milk was recirculated in batch mode at $15^{\circ} \mathrm{C}$ with a pressure of $3.79 \mathrm{MPa}$ and a flow rate of $55 \mathrm{~L} / \mathrm{min}$. Total solids were measured by a rapid moisture analyzer (SMART Trac II, CEM Corp., Matthews, NC). All spray drying was performed with a pilot-scale spray dryer (model Lab 1, Anhydro Inc., Soeberg, Denmark) with an inlet temperature of $200^{\circ} \mathrm{C}$ and an outlet temperature of $90^{\circ} \mathrm{C}$. The entire experiment was replicated 3 separate times.

Experiment 2. To further investigate the effect of evaporation on the retention of volatile flavor compounds, a second experiment was performed. Raw skim 
milk was obtained from the North Carolina State University Dairy Research and Education Unit. The skim milk was pasteurized as described previously. A portion of the pasteurized skim milk was saved as a control, and the rest was subjected to one of the following treatments: $(\mathrm{A})$ heating $\left(63^{\circ} \mathrm{C}\right)$ in the evaporator with no vacuum, (B) condensed to $30 \%$ solids (wt/wt) with vacuum, and $(\mathrm{C})$ condensed to $40 \%$ solids (wt/wt) with vacuum. Calandria temperature was $71^{\circ} \mathrm{C}$ and vacuum was $74.5 \mathrm{kPa}$ for treatments $\mathrm{B}$ and $\mathrm{C}$. The temperature for treatment $\mathrm{A}$ was $63^{\circ} \mathrm{C}$ because that was the temperature of the condensed milk exiting the calandria and the temperature at which the milk spends the majority of the time. All milks were subsequently cooled to $4^{\circ} \mathrm{C}$ and sampled. The condensed milks were diluted to the original percent solids as the pasteurized skim milk with deionized water. Descriptive and volatile compound analyses on the milks were performed as described below. In addition, 3 solid-phase micro-extraction fibers (2 $\mathrm{cm}$ divynylbenzene/carboxen/polydimethylsiloxane fiber, Supelco, Bellefonte, PA) were exposed for $15 \mathrm{~min}$ through a silicone septa (Fisher Scientific, Waltham, $\mathrm{MA}$ ) in the vapor separator of the evaporator during manufacture of treatments $\mathrm{A}, \mathrm{B}$, and $\mathrm{C}$. The $\mathrm{pH}$ of the undiluted condensed milks and original milk was measured at $63^{\circ} \mathrm{C}$ using a pH meter (VWR International, Radnor, PA) calibrated with buffers at $63^{\circ} \mathrm{C}$. This entire experiment was replicated 3 times.

\section{Proximate Analysis}

Moisture in NFDM was measured using vacuum oven drying (AOAC International, 2000; method 990.20; 33.2.44). Total fat in NFDM was determined by ether extraction (AOAC International, 2000; method 923.06; 33.5.08). Total protein was measured using the Kjeldahl method and multiplying total nitrogen by a conversion factor of 6.38 (AOAC International, 2000; method 991.20; 33.2.11). Whey protein nitrogen index was measured as described by ADPI (2002).

\section{Powder Particle Size, Surface Free Fat}

Powder particle size of the NFDM in experiment 1 was measured using a Mastersizer 3000 (Malvern, Malvern, UK) with an Aero S dry powder dispenser. Surface free fat was measured by a petroleum ether extraction (GEA Niro Method No. 10a; GEA, 2005).

\section{Descriptive Sensory Analysis}

All descriptive sensory analysis was done in compliance with the North Carolina State University Institutional Review Board for Human Subjects guidelines.
The NFDM was rehydrated to $10 \%$ solids (wt/vol) in deionized water with a handheld blender until fully dissolved. The NFDM solutions were dispensed into 60-mL soufflé cups (Solo Cup, Highland Park, IL). They were then lidded and tempered to $21^{\circ} \mathrm{C}$. Flavor attributes were evaluated using the 0 to 15 Spectrum intensity scale with a trained panel $(\mathrm{n}=8)$. Panelists were between the ages of 22 and $47 \mathrm{yr}$ with $>150 \mathrm{~h}$ of previous experience with descriptive analysis of dried dairy ingredients using an established lexicon (Drake et al., 2003). Data were collected using Compusense Cloud (Compusense, Guelph, ON, Canada).

\section{Volatile Compound Analysis}

Experiment 1. Volatile compounds in experiment 1 were extracted using sorptive stir bar extraction (Prieto et al., 2010). Each NFDM manufacture replicate was extracted in triplicate. Prior to analysis, the stir bars and thermal desorption unit (TDU) tubes were conditioned for $1 \mathrm{~h}$ at $300^{\circ} \mathrm{C}$. First, $0.5 \mathrm{~g}$ of NFDM was placed into a $10-\mathrm{mL}$ amber screw-top vial (Gerstel Inc., Linthicum, MD) along with $5 \mathrm{~mL}$ of HPLC-grade water. Next, $10 \mu \mathrm{L}$ of internal standard was added (0.81 mg $/ \mathrm{kg}$ of 2-methyl-3-heptanone in water, Sigma Aldrich, St. Louis, MO). Sequential stir bar extraction was used because the adsorption of compounds onto the polydimethylsiloxane (PDMS) layer is affected by the addition of salt. Polar compounds are extracted more effectively with salt, whereas hydrophobic compounds are extracted more efficiently without salt (Prieto et al., 2010). Sequential stir bar extraction allows for the extraction of both classes of compounds. Preliminary experiments determined that the extraction of volatile compounds of interest increased with sequential stir bar extraction using $20 \%$ salt in the second extraction compared with 1 stir bar alone or 2 stir bars simultaneously (data not shown). One PDMS-coated stir bar (10 $\mathrm{mm} \times 0.5 \mathrm{~mm}$ thickness, Gerstel Inc.) was placed in the vial, sealed, and stirred for $1 \mathrm{~h}$ at $1000 \mathrm{rpm}$. After 1 $\mathrm{h}$, the stir bar was briefly rinsed in HPLC-grade water, dried, and placed in an autosampler tube (Gerstel Inc.) and $1 \mathrm{~g}$ of $\mathrm{NaCl}$ was added along with another PDMS stir bar into the sample vial. This stir bar was stirred for $1 \mathrm{~h}$ at 1,000 rpm, rinsed, dried, and placed in the same TDU tube previously mentioned. Stir bars were injected using an autosampler (MPS Autosampler, Gerstel Inc.). The stir bars were desorbed at $250^{\circ} \mathrm{C}$ for 10 min (TDU, Gerstel Inc.) and the volatile compounds were cryogenically trapped at $-120^{\circ} \mathrm{C}$ (CIS 4, Gerstel Inc.).

Volatile compounds were analyzed by GC-MS. An Agilent 7890B GC (Agilent Technologies Inc., Santa Clara, CA) with an inert mass selective detector (mod- 
el 5970A, Agilent Technologies Inc.) with a ZB-5MS column $(30 \mathrm{~m} \times 0.25 \mathrm{~mm} \times 0.25 \mu \mathrm{m}$; Phenomenex, Torrance, CA) was used to identify and quantify volatile compounds of interest (Karagul-Yuceer et al., 2001; Karagul-Yuceer et al., 2002; Drake et al., 2007). Initial $\mathrm{GC}$ oven conditions were $40^{\circ} \mathrm{C}$ for $3 \mathrm{~min}$ with ramp rates of $10^{\circ} \mathrm{C} / \mathrm{min}$ to $90^{\circ} \mathrm{C}, 5^{\circ} \mathrm{C} / \mathrm{min}$ to $200^{\circ} \mathrm{C}$ held for 10 min, and $20^{\circ} \mathrm{C} / \mathrm{min}$ to $250^{\circ} \mathrm{C}$ held for $5 \mathrm{~min}$. Purge time was set to 1.2 min using helium as the carrier gas at a constant flow rate of $1 \mathrm{~mL} / \mathrm{min}$. Compounds were identified by comparison with the 2014 NIST mass spectral library (NIST, 2014), retention index, and retention time of authentic standards injected under identical conditions. Relative abundance of selected compounds was calculated using recovery of the internal standard.

Experiment 2. Volatile compounds of the milks diluted to the original percent solids (approximately $9 \% \mathrm{wt} / \mathrm{wt}$ ) were analyzed as described for experiment 1. Volatile compounds that were extracted in the vapor separator of the evaporator were identified qualitatively by GC-olfactometry (GC-O) as well as by GC-MS. The GC-O analysis was performed with a gas chromatograph with a flame ionization detector and olfactometry port (model 6850, Agilent Technologies Inc.) and the same nonpolar column in experiment 1 . Two highly trained sniffers ( $>50 \mathrm{~h}$ experience each) sniffed each sample once. Oven temperature program was as follows: $40^{\circ} \mathrm{C}$ held for $3 \mathrm{~min}, 10^{\circ} \mathrm{C} / \mathrm{min}$ gradual increase to $150^{\circ} \mathrm{C}$, and $30^{\circ} \mathrm{C} / \mathrm{min}$ gradual increase to $200^{\circ} \mathrm{C}$ held for $10 \mathrm{~min}$. The GC-MS analysis was performed on an Agilent 7820A GC (Agilent Technologies Inc.) with an inert mass selective detector (model 5975 MSD, Agilent Technologies Inc.). Column and oven temperature program were the same as in experiment 1 . All fibers were exposed into the column inlet at $250^{\circ} \mathrm{C}$. Helium carrier gas was used on both GC-O and GC-MS at a rate of 1 $\mathrm{mL} / \mathrm{min}$ with a purge time of $1.5 \mathrm{~min}$.

\section{Furosine Analysis}

Furosine (FUR) was measured in NFDM as described by Resmini et al. (1990) with minor modifications. Between 110 and $140 \mathrm{mg}$ of NFDM was accurately weighed into a screw-cap Pyrex tube with a PTFE-lined septa along with $8 \mathrm{~mL}$ of $10.6 \mathrm{M} \mathrm{HCl}$ (Sigma Aldrich). Nitrogen gas was bubbled through the samples for $2 \mathrm{~min}$ and then capped and heated to $110^{\circ} \mathrm{C}$ for $23 \mathrm{~h}$. After cooling to room temperature, the hydrolysate was filtered and $0.5 \mathrm{~mL}$ of filtrate was loaded onto a solid-phase extraction column (500 mg Discovery DSC-18, Supelco) previously conditioned with $5 \mathrm{~mL}$ of methanol followed by $10 \mathrm{~mL}$ of water. The FUR was eluted with $3 \mathrm{~mL}$ of $3 \mathrm{M} \mathrm{HCl}$. Detection was performed with a Waters HPLC system (Milford,
MA). A FUR dedicated column was used (Altima C8, $250 \times 4.6 \mathrm{~mm}, 5 \mu \mathrm{m}$, Alltech-Grace, Columbia, MD) with isocratic conditions. The mobile phase consisted of $0.4 \%$ acetic acid (Sigma Aldrich) and the column temperature was $35^{\circ} \mathrm{C}$. Ultraviolet detection was performed at $280 \mathrm{~nm}$. A 5-point external standard curve ranging from 50 to $400 \mathrm{ng}$ was constructed for quantification.

\section{Statistical Analysis}

The data were analyzed by 2-way ANOVA with means separation (SAS version 9.3, SAS Institute Inc., Cary, NC). Interaction effects between storage time and method of concentration to $30 \%$ solids were investigated. Differences between sample means were analyzed using Fisher's least significant difference test.

\section{RESULTS}

\section{Experiment 1}

The fat content in the NFDM was $0.743 \pm 0.11 \%$ (wt/wt) and was not different among treatments and replications $(P>0.05)$. Moisture in the NFDM was $3.01 \pm 0.23 \%$ and was not different among treatments and replications $(P>0.05)$. Protein and whey protein nitrogen index were not different among treatments and replications and were $36.1 \pm 0.25 \%$ (wt/wt) and $7.76 \pm 0.27 \mathrm{mg} / \mathrm{g}$, respectively $(P>0.05)$.

Descriptive analysis results indicated that the flavor profiles of the different NFDM treatments were distinct (Table 1). Interaction effects between method of concentration (RO vs. E) and storage time were not significant $(P>0.05)$. The use of RO in place of $\mathrm{E}$ for concentration to $30 \%$ solids (wt/wt) increased sweet aromatic flavor intensity $(2.8$ vs. $2.2 ; P<0.05)$ and decreased cardboard (ND vs. 1.1) and cooked (2.9 vs. 3.6; $P<0.05)$ flavor intensities. Storage of condensed milk for $24 \mathrm{~h}$ increased cardboard flavor intensity (1.1 vs. ND) and decreased sweet aromatic flavor intensity (2.2 vs. $2.8 ; P<0.05)$.

The volatile compound profiles of the different spraydried NFDM treatments were also distinct (Figure 2, Table 2) and consistent with sensory results. In general, the RO treatments had increased volatile compound concentrations compared with the $\mathrm{E}$ treatments $(P$ $<0.05$ ). Use of RO to concentrate to $30 \%$ (wt/wt) increased concentrations of furfural, hexanal, vanillin, $\delta$-nonalactone, $\delta$-decalactone, 2,4-nonadienal, butyric acid, hexanoic acid, octanoic acid, decanoic acid, dodecanoic acid, tridecanoic acid, 1-octen-3-one, and benzaldehyde and decreased the concentration of maltol $(P<0.05)$. Many of these compounds are attributed to sweet aromatic flavor in milk powders (Karagul Yuceer 
Table 1. Descriptive sensory means of rehydrated nonfat dry milk powders with or without $24 \mathrm{~h}$ of liquid storage and processed by reverse osmosis $(\mathrm{RO})$ or evaporation $(\mathrm{E})^{1}$

\begin{tabular}{|c|c|c|c|c|c|}
\hline Item & Variable & Overall aroma & Sweet aromatic & Cooked & Cardboard \\
\hline
\end{tabular}

${ }_{\mathrm{a}, \mathrm{b}}$ Means in the same column and within storage time or method of concentration not sharing a common superscript are different $(P<0.05)$.

${ }^{1}$ Attribute intensities were scored on a 0- to 15-point universal intensity scale (Meilgaard et al., 2009). Most dried ingredient flavors fall between 0 and 4 on this scale (Drake et al., 2003). Interaction effects were not significant $(P>0.05)$. ND $=$ not detected.

et al., 2001; Drake et al., 2007) and explain the higher sweet aromatic intensity. Storage time also affected the volatile compound profile of the NFDM $(P<0.05)$. Storage of $30 \%$ solids (wt/wt) condensed milk decreased the concentration of vanillin, and increased the concentrations of hexanal, octanal, and 2,4-nonadienal $(P<0.05)$. These aldehyde compounds are attributed to cardboard flavor in dried ingredients (Drake et al., 2007; Whitson et al., 2010).
Furosine is a product of early Maillard reactions and is used as an indicator of heat treatment. Furosine was only affected by the method of concentration to $30 \%$ solids (wt/wt; Figure 3). The RO decreased FUR concentration compared with E (30.9 vs. $41.6 \mathrm{mg}$ of FUR/100 g of protein; $P<0.05$ ). This is most likely due to the fact that the milk during $\mathrm{RO}$ was $<15^{\circ} \mathrm{C}$ compared with elevated temperatures during $\mathrm{E}\left(>63^{\circ} \mathrm{C}\right)$. During heating of milk, lysine residues of proteins

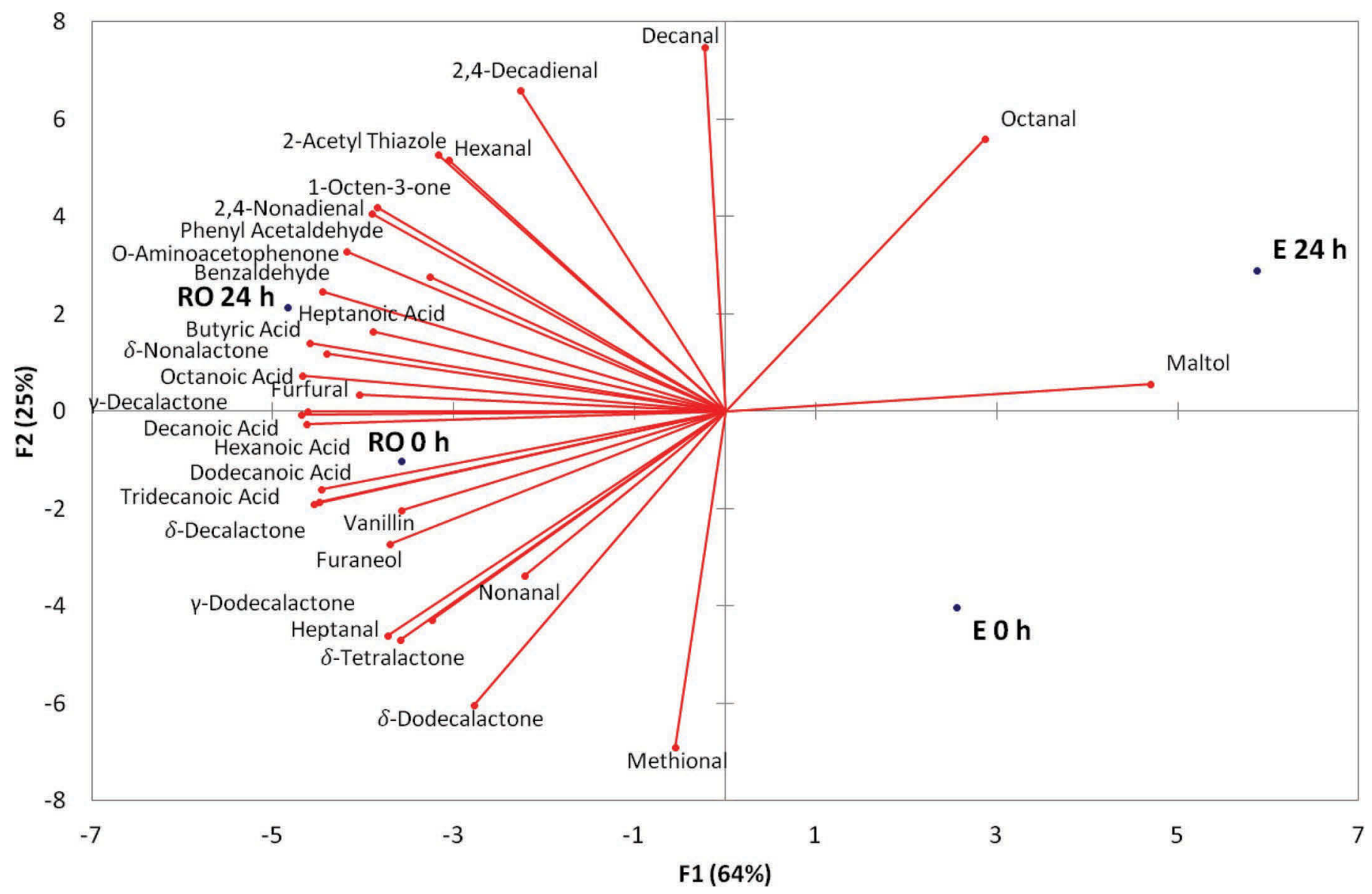

Figure 2. Principal component analysis biplot of volatile compound profiles of nonfat dry milk $(\mathrm{NFDM}) . \mathrm{E}=$ evaporation, RO $=$ reverse osmosis, $0 \mathrm{~h}=$ no storage; $24 \mathrm{~h}=24 \mathrm{~h}$ of storage. Color version available online. 
Table 2. Relative abundance $(\mu \mathrm{g} / \mathrm{kg})$ of selected volatile compounds of nonfat dry milk powders with or without $24 \mathrm{~h}$ of liquid storage and processed by reverse osmosis $(\mathrm{RO})$ or evaporation $(\mathrm{E})^{1}$

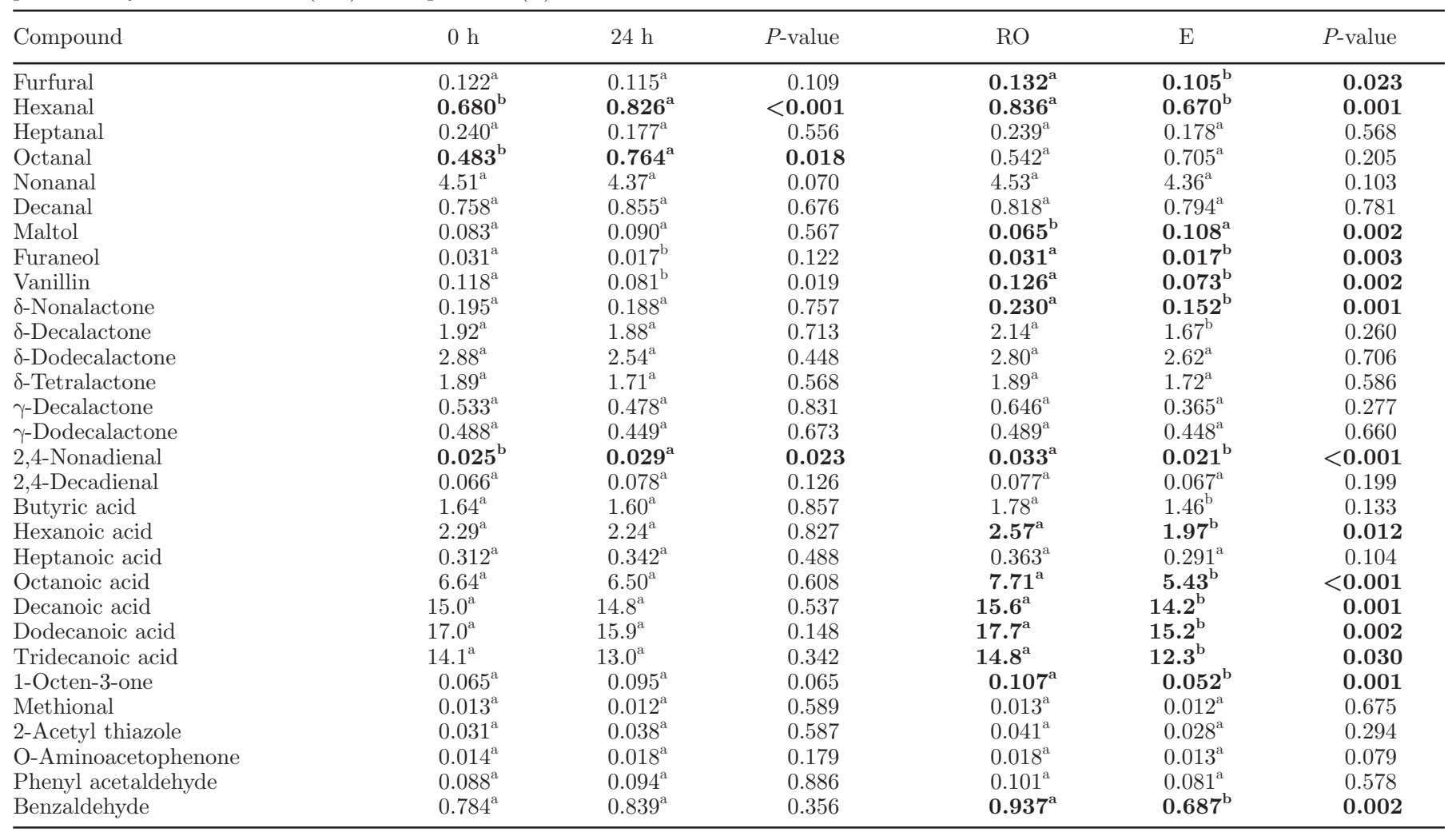

${ }^{\mathrm{a}, \mathrm{b}}$ Means in the same section followed by different superscripts indicate significant differences $(P<0.05)$.

${ }^{1}$ Interaction effects between method of concentration and storage time were not significant for any compounds $(P>0.05)$. Significant differences $(P<0.05)$ are highlighted in bold.

react with lactose, forming lactulosyl-lysine (Mehta and Deeth, 2015). Because other reducing sugars can react with lysine forming, for example, fructosyl-lysine or glucosyl-lysine, all of the sugar-lysine products are converted to FUR by acid hydrolysis to then be quantified (Resmini et al., 1990; Mehta and Deeth, 2015). The decreased water content in the condensed milks compared with the original skim milk could have also increased the Maillard reaction when heated during E.

The powder particle size distribution of the NFDM were distinct (Table 3). Surface free fat (SFF) was not different among treatments $(P>0.05)$ and averaged $1.28 \mathrm{~g}$ of SFF/100 g of total fat. Interaction effects between storage time and method of concentration were significant $(P<0.05)$. Storage of liquid E condensed skim milk increased the average powder particle size $(\mathbf{D}[4,3])$ and the powder particle size distribution of the NFDM compared with all other treatments $(P<$ 0.05). In contrast, storage of RO condensed skim milk decreased the $\mathrm{D}[4,3]$ and the size distribution of NFDM compared with all other treatments $(P<0.05)$. The $\mathrm{E}$ increased the $\mathrm{D}[4,3](63.9$ vs. $48.1 \mu \mathrm{m})$ and size distri- bution compared with $\mathrm{RO}$ when condensed skim milk was stored for $24 \mathrm{~h}(P<0.05)$, but when no storage was applied, E decreased the $\mathrm{D}[4,3](58.0$ vs. $51.0 \mu \mathrm{m})$ and size distribution compared with RO $(P<0.05)$.

\section{Experiment 2}

The descriptive sensory means of the different treatments in experiment 2 are shown in Table 4. Heating the milk in the evaporator with no vacuum (treatment A) decreased overall aroma and sweet aromatic flavors and increased astringency compared with the unheated control $(P<0.05)$. Condensing milk to 30 or $40 \%$ solids (treatments $\mathrm{B}$ and $\mathrm{C}$, respectively) removed much of the aroma and characteristic milk flavors. These flavor effects were observed with a decrease in overall aroma and sweet aromatic flavor and an increase in cardboard flavor compared with the control and treatment A $(P$ $<0.05$ ). Evaporation to $30 \%$ or $40 \%$ increased astringency compared with the control, and evaporation to $40 \%$ also increased astringency compared with treatment A $(P<0.05)$. 


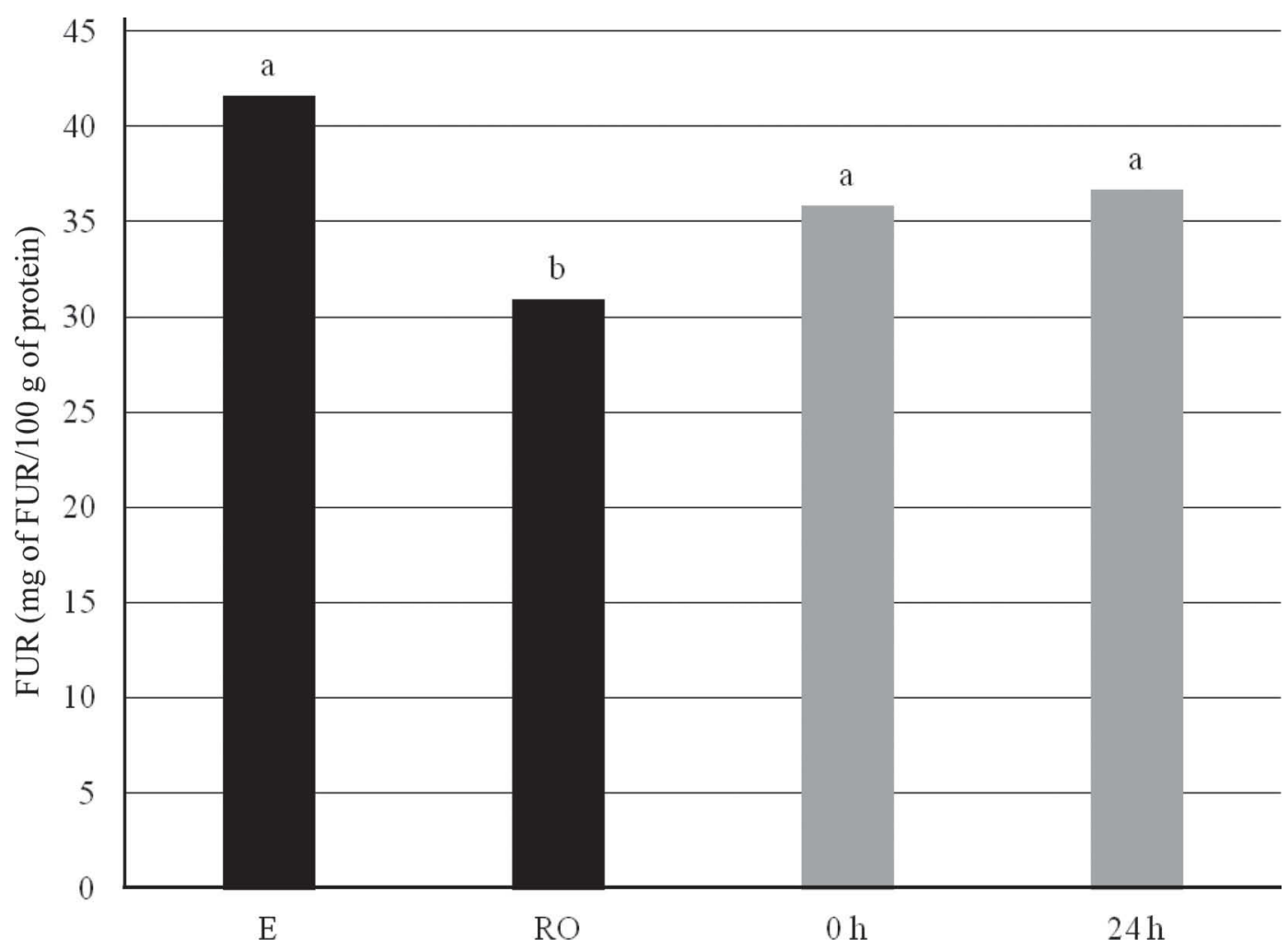

Figure 3. Furosine (FUR) content in nonfat dry milk (mg of FUR/100 g of protein) with or without 24 h of liquid storage and processed by reverse osmosis $(\mathrm{RO})$ or evaporation $(\mathrm{E})$. Bars with the same color and different letters are significantly different $(P<0.05)$. Interaction effects between storage time and method of concentration were not significant $(P>0.05)$.

Table 3. Particle size of nonfat dry milk powders with or without $24 \mathrm{~h}$ of liquid storage and processed by reverse osmosis $(\mathrm{RO})$ or evaporation $(\mathrm{E})^{1}$

\begin{tabular}{lcccc}
\hline Treatment & $\operatorname{Dx}(10)$ & $\operatorname{Dx}(50)$ & $\operatorname{Dx}(90)$ & $\mathrm{D}[4,3]$ \\
\hline E 24 h & $0.858^{\mathrm{a}}$ & $55.8^{\mathrm{a}}$ & $129^{\mathrm{a}}$ & $63.9^{\mathrm{a}}$ \\
RO 0 h & $0.609^{\mathrm{c}}$ & $48.0^{\mathrm{b}}$ & $114^{\mathrm{b}}$ & $58.0^{\mathrm{b}}$ \\
E 0 h & $0.679^{\mathrm{b}}$ & $46.0^{\mathrm{c}}$ & $106^{\mathrm{c}}$ & $51.0^{\mathrm{c}}$ \\
RO 24 h & $0.599^{\mathrm{c}}$ & $42.6^{\mathrm{d}}$ & $96.5^{\mathrm{d}}$ & $48.1^{\mathrm{d}}$ \\
\hline
\end{tabular}

$\overline{\mathrm{a}-\mathrm{d}}$ Numbers in the same column followed by a different superscript are significantly different $(P<0.05)$.

${ }^{1}$ Interaction effects between storage time and method of concentration were significant $(P<0.05)$. Dx $(10)=$ $10 \%$ of particles below that value, $\mathrm{Dx}(50)=50 \%$ of particles below that value, $\mathrm{Dx}(90)=90 \%$ of particles below that value. $\mathrm{D}[4,3]=$ volumetric mean.

Table 4. Descriptive sensory means for skim milks diluted to $9 \%$ solids from experiment $2^{1}$

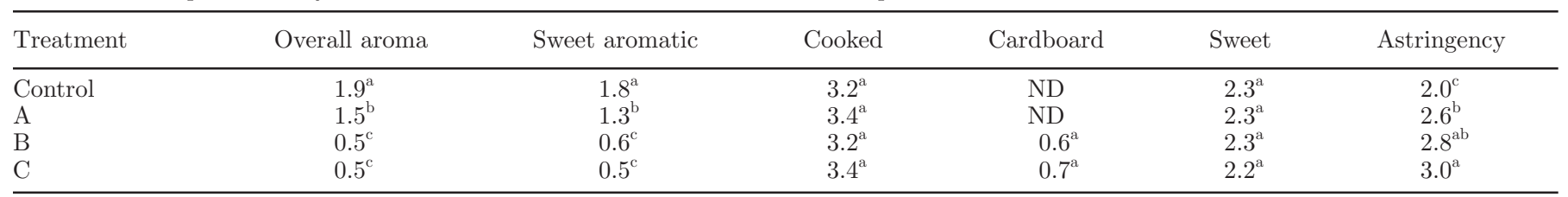

\footnotetext{
${ }^{\mathrm{a}-\mathrm{c}}$ Means in the same column not sharing a common superscript are different $(P<0.05)$.
}

${ }^{1}$ Treatment A: Heated in evaporator without vacuum; treatment B: evaporated to $30 \%$ solids (wt/wt); treatment C: evaporated to $40 \%$ solids (wt/wt). Attribute intensities were scored on a 0- to 15-point universal intensity scale (Meilgaard et al., 2009). Most dried ingredient flavors fall between 0 and 4 on this scale (Drake et al., 2003). Interaction effects were not significant $(P>0.05)$. ND $=$ not detected. 
Table 5. Relative abundance $(\mu \mathrm{g} / \mathrm{kg})$ of selected volatile compounds in skim milks from experiment 2

\begin{tabular}{|c|c|c|c|c|}
\hline \multirow[b]{2}{*}{ Volatile compound } & \multicolumn{4}{|c|}{ Treatment } \\
\hline & Control & $\mathrm{A}$ & B & $\mathrm{C}$ \\
\hline Furfural & $0.203^{\mathrm{a}}$ & $0.192^{\mathrm{ab}}$ & $0.171^{\mathrm{ab}}$ & $0.151^{\mathrm{b}}$ \\
\hline Hexanal & $1.08^{\mathrm{a}}$ & $1.07^{\mathrm{a}}$ & $0.490^{\mathrm{b}}$ & $0.490^{\mathrm{b}}$ \\
\hline Heptanal & $0.009^{\mathrm{a}}$ & $0.009^{\mathrm{a}}$ & $0.010^{\mathrm{a}}$ & $0.008^{\mathrm{a}}$ \\
\hline Octanal & $0.175^{\mathrm{c}}$ & $0.203^{\mathrm{bc}}$ & $0.324^{\mathrm{a}}$ & $0.238^{\mathrm{b}}$ \\
\hline Nonanal & $2.60^{\mathrm{b}}$ & $2.83^{\mathrm{ab}}$ & $3.14^{\mathrm{a}}$ & $3.16^{\mathrm{a}}$ \\
\hline Decanal & $0.528^{\mathrm{c}}$ & $0.507^{\mathrm{c}}$ & $0.985^{\mathrm{a}}$ & $0.718^{\mathrm{b}}$ \\
\hline Maltol & $0.089^{\mathrm{a}}$ & $0.023^{\mathrm{b}}$ & $0.017^{\mathrm{b}}$ & $0.018^{\mathrm{b}}$ \\
\hline Furaneol & $0.037^{\mathrm{a}}$ & $0.034^{\mathrm{a}}$ & $0.019^{\mathrm{b}}$ & $0.022^{\mathrm{b}}$ \\
\hline Vanillin & $0.016^{\mathrm{a}}$ & $0.015^{\mathrm{a}}$ & $0.008^{\mathrm{b}}$ & $0.008^{\mathrm{b}}$ \\
\hline$\delta$-Nonalactone & $0.136^{\mathrm{a}}$ & $0.144^{\mathrm{a}}$ & $0.052^{\mathrm{b}}$ & $0.060^{\mathrm{b}}$ \\
\hline$\delta$-Decalactone & $0.480^{\mathrm{a}}$ & $0.503^{\mathrm{a}}$ & $0.250^{\mathrm{b}}$ & $0.249^{\mathrm{b}}$ \\
\hline$\delta$-Dodecalactone & $0.058^{\mathrm{a}}$ & $0.050^{\mathrm{a}}$ & $0.061^{\mathrm{a}}$ & $0.047^{\mathrm{a}}$ \\
\hline$\delta$-Tetralactone & $0.063^{\mathrm{a}}$ & $0.039^{\mathrm{a}}$ & $0.044^{\mathrm{a}}$ & $0.048^{\mathrm{a}}$ \\
\hline$\gamma$-Decalactone & $0.123^{\mathrm{a}}$ & $0.147^{\mathrm{a}}$ & $0.096^{\mathrm{a}}$ & $0.090^{\mathrm{a}}$ \\
\hline$\gamma$-Dodecalactone & $0.042^{\mathrm{a}}$ & $0.037^{\mathrm{a}}$ & $0.038^{\mathrm{a}}$ & $0.035^{\mathrm{a}}$ \\
\hline 2,4-Nonadienal & $0.009^{\mathrm{a}}$ & $0.008^{\mathrm{a}}$ & $0.003^{\mathrm{b}}$ & $0.003^{\mathrm{b}}$ \\
\hline 2,4-Decadienal & $0.022^{\mathrm{a}}$ & $0.025^{\mathrm{a}}$ & $0.014^{\mathrm{b}}$ & $0.014^{\mathrm{b}}$ \\
\hline Butyric acid & $0.747^{\mathrm{a}}$ & $0.659^{\mathrm{ab}}$ & $0.571^{\mathrm{b}}$ & $0.595^{\mathrm{b}}$ \\
\hline Hexanoic acid & $1.51^{\mathrm{a}}$ & $1.43^{\mathrm{ab}}$ & $1.04^{\mathrm{c}}$ & $1.26^{\mathrm{bc}}$ \\
\hline Heptanoic acid & $0.141^{\mathrm{a}}$ & $0.116^{\mathrm{ab}}$ & $0.106^{\mathrm{ab}}$ & $0.097^{\mathrm{b}}$ \\
\hline Octanoic acid & $4.48^{\mathrm{a}}$ & $4.73^{\mathrm{a}}$ & $2.69^{\mathrm{b}}$ & $2.84^{\mathrm{b}}$ \\
\hline Decanoic acid & $2.22^{\mathrm{a}}$ & $2.27^{\mathrm{a}}$ & $1.59^{\mathrm{b}}$ & $1.56^{\mathrm{b}}$ \\
\hline Dodecanoic acid & $1.51^{\mathrm{a}}$ & $1.60^{\mathrm{a}}$ & $1.17^{\mathrm{a}}$ & $1.18^{\mathrm{a}}$ \\
\hline 1-Octen-3-one & $0.019^{\mathrm{ab}}$ & $0.023^{\mathrm{a}}$ & $0.019^{\mathrm{ab}}$ & $0.014^{\mathrm{b}}$ \\
\hline 2-Acetyl thiazole & $0.003^{\mathrm{a}}$ & $0.002^{\mathrm{ab}}$ & $0.002^{\mathrm{ab}}$ & $0.001^{\mathrm{b}}$ \\
\hline O-Aminoacetophenone & $0.004^{\mathrm{a}}$ & $0.004^{\mathrm{a}}$ & $0.003^{\mathrm{a}}$ & $0.004^{\mathrm{a}}$ \\
\hline Phenyl acetaldehyde & $0.009^{\mathrm{b}}$ & $0.009^{\mathrm{b}}$ & $0.012^{\mathrm{a}}$ & $0.009^{\mathrm{b}}$ \\
\hline Dimethyl disulfide & $0.695^{\mathrm{a}}$ & $0.646^{\mathrm{a}}$ & $0.669^{\mathrm{a}}$ & $0.692^{\mathrm{a}}$ \\
\hline Benzaldehyde & $0.245^{\mathrm{b}}$ & $0.332^{\mathrm{a}}$ & $0.390^{\mathrm{a}}$ & $0.333^{\mathrm{a}}$ \\
\hline
\end{tabular}

${ }^{\mathrm{a}-\mathrm{c}}$ Means in the same row followed by different superscripts indicate significant differences $(P<0.05)$.

The volatile compound profiles of the evaporator treatments in experiment 2 were in agreement with the descriptive sensory results (Table 5, Figure 4). In general, concentration of the milk by evaporation decreased the flavor compound concentrations. This was observed with decreases in furfural, hexanal, maltol, furaneol, vanillin, $\delta$-nonalactone, $\delta$-decalactone, 2,4-nonadienal, 2,4-decadienal, butyric acid, hexanoic acid, octanoic acid, decanoic acid, and 2-acetyl-thiazaole compared with the control $(P<0.05)$. Many of these compounds were also identified in the vapor separator of the evaporator (Table 6).

The skim milk, $30 \%$ condensed milk, and $40 \%$ condensed milk $\mathrm{pH}$ values at $63^{\circ} \mathrm{C}$ were $6.57 \pm 0.02,6.25$ \pm 0.01 , and $6.17 \pm 0.01$, respectively. The $\mathrm{pH}$ was measured at $63^{\circ} \mathrm{C}$ because that was the temperature of the condensed milk in the vapor separator. The $\mathrm{pH}$ of the condensed milk in the vapor separator could play a large role in the solubility of the flavor compounds and therefore influence their partitioning out of the milk and into the headspace air going to the vacuum pump. In general, acidic volatile compounds decrease in solubility with decreasing $\mathrm{pH}$ and therefore would be more easily removed by vacuum evaporation.

\section{DISCUSSION}

The flavor of dried dairy ingredients can be grouped into 1 of 2 groups: dairy and nondairy flavors (Carunchia Whetstine et al., 2005). During the storage of SMP/ NFDM, sweet aromatic flavor decreases while nondairy flavors such as cardboard and potato/brothy develop (Karagul-Yuceer et al., 2002; Caudle et al., 2005; Drake et al., 2007). To increase the shelf-life of NFDM, it is then important to preserve fresh milk flavors such as sweet aromatic flavor. We observed a decrease in dairy flavors in NFDM and an increase in nondairy flavors when solely E was used and when liquid condensed milk was stored for even just $24 \mathrm{~h}$. These unit operations could have a detrimental effect on the shelf-life and consumer acceptance of ingredient applications that use NFDM (Caudle et al., 2005).

Karagul-Yuceer et al. (2001) and (2004) identified and confirmed volatile compounds in NFDM with high odor activity and flavor effect. These compounds were identified as furaneol, butyric acid, methional, o-aminoacetophenone, $\delta$-decalactone, vanillin, hexanoic acid, 2-acetyl-1-pyrroline, octanoic acid, $\gamma$-dodecalactone, 2,4-decadienal, and maltol. Drake et al. (2007) also re- 


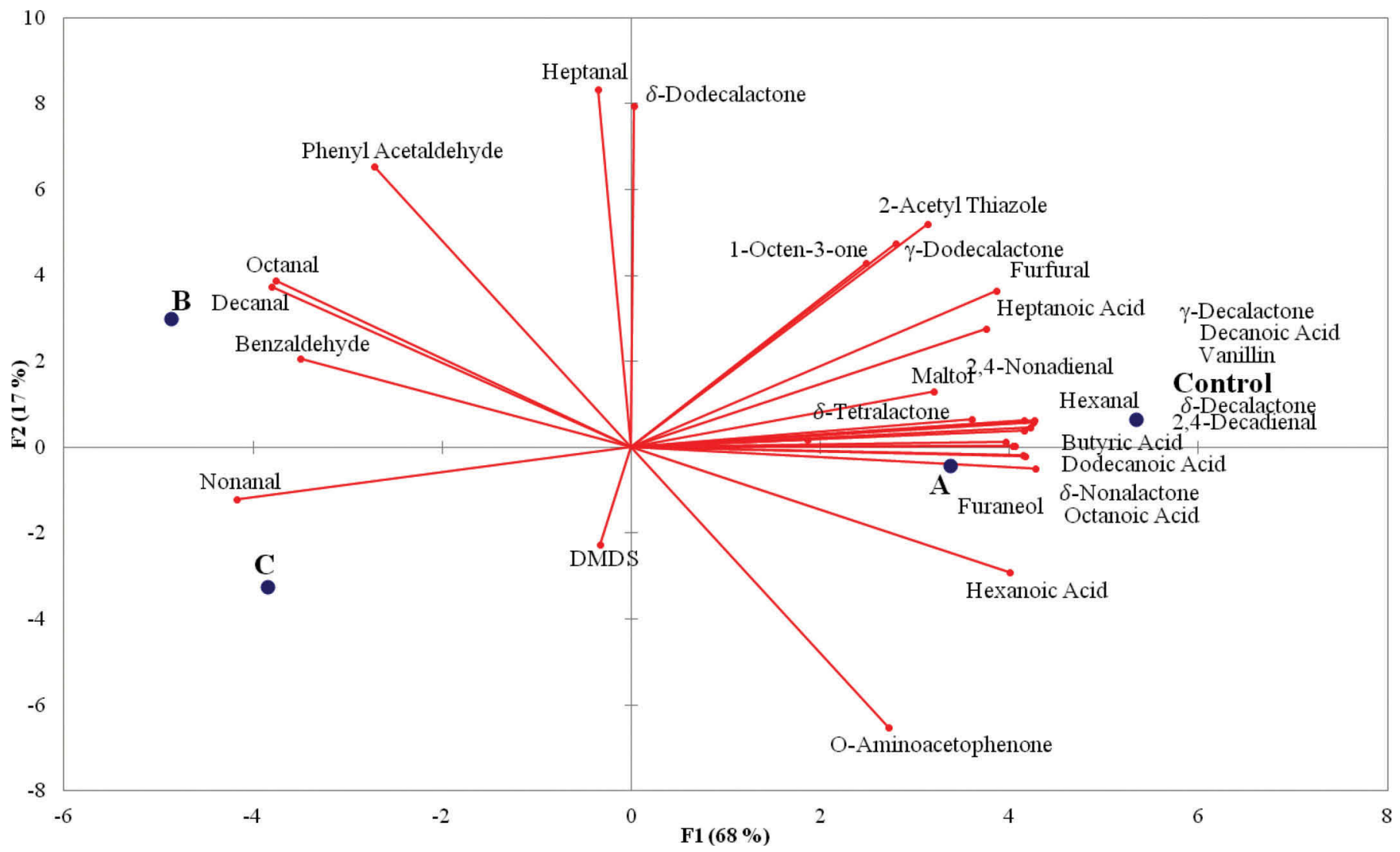

Figure 4. Principal component analysis biplot of volatile compound profiles of skim milks from experiment 2 . Treatment $\mathrm{A}=$ heated in evaporator without vacuum; treatment $\mathrm{B}=$ evaporated to $30 \%$ solids (wt/wt); treatment $\mathrm{C}=$ evaporated to $40 \%$ solids (wt/wt). $\mathrm{DMDS}=$ dimethyl disulfide. Color version available online.

ported many of these compounds in fresh SMP/NFDM and documented that they decreased with storage at $21^{\circ} \mathrm{C}$, whereas lipid oxidation compounds increased in relative abundance. In experiment 1, we observed decreases in furaneol, vanillin, $\delta$-decalactone, butyric acid, hexanoic acid, and octanoic acid when $\mathrm{E}$ was used to concentrate to $30 \%$ solids instead of RO $(P<$ 0.05). Experiment 2 further demonstrated that these compounds were being removed with the water vapor as they decreased in concentration with treatments $\mathrm{B}$ and $\mathrm{C}$ and were identified in the vapor separator. This supports the descriptive sensory results where a decrease in sweet aromatic flavor was observed, a characteristic dairy flavor. Evaporation increased cooked flavor in the NFDM compared with RO, which can be explained by the increased heating during the unit operation of evaporation and was confirmed with increased maltol and FUR concentrations $(P<0.05)$. Maltol is a product of the Maillard reaction and was demonstrated to be in higher concentrations in milk powders that were exposed to more heat (Pischetsrieder et al., 1999; Karagul-Yuceer et al., 2001). In general, lipid oxidation compounds did not increase with E compared with RO. Cardboard flavor did increase in E NFDM and cardboard flavor has been linked to volatile lipid oxidation products (Whitson et al., 2010). We hypothesize that the higher cardboard flavor in E NFDM was attributed to the lower sweet aromatic flavor. In the NFDM produced with only E, the sweet aromatic decreased in intensity and therefore cardboard flavor was perceived more readily by the trained panel. Cardboard flavor was not detected in RO NFDM even though lipid oxidation products were detected. This is most likely due to the increased sweet aromatic flavor intensity masking cardboard flavor perception. Park et al. (2014) demonstrated that spray-drying parameters significantly affected the flavor of whey protein concentrate $80 \%$ with certain conditions increasing cardboard flavor intensity. Because experiment 2 demonstrated that a wide range of volatile compounds were removed during $\mathrm{E}$, the effect of spray drying on the flavor of NFDM could be magnified. This is because variations in spray-drying parameters influence flavor and this flavor variability 
Table 6. Volatile compounds identified in the vapor separator of the evaporator during production of 30 and $40 \%$ solids (wt/wt) condensed skim milk (experiment 2$)^{1}$

\begin{tabular}{|c|c|c|c|}
\hline Compound & $\begin{array}{l}\text { Method of } \\
\text { identification }\end{array}$ & Odor & RI \\
\hline Diacetyl & RI, MS & ND & $<600$ \\
\hline Acetic acid & RI, MS & ND & $<600$ \\
\hline Dimethyl sulfide & $\mathrm{RI}, \mathrm{O}$ & Sulfur, garbage & $<600$ \\
\hline Butryic acid & RI, O, MS & Cheesy & 801 \\
\hline Hexanal & $\mathrm{RI}, \mathrm{O}, \mathrm{MS}$ & Grassy & 803 \\
\hline Furfuryl alcohol & RI, O, MS & Rubber & 861 \\
\hline 2-Acetylpyrroline & $\mathrm{RI}, \mathrm{O}$ & Cooked, roasted & 878 \\
\hline Methional & RI, O, MS & Cooked potato & 896 \\
\hline Heptanal & RI, MS & ND & 901 \\
\hline 1-Octen-3-one & RI, O & Mushroom & 986 \\
\hline Hexanoic acid & RI, MS & ND & 993 \\
\hline Octanal & RI, MS & ND & 1,007 \\
\hline 2-Acetyl-2-thiazoline & RI, O & Toasted grain & 1,044 \\
\hline Furaneol & RI, O, MS & Sweet, caramel & 1,056 \\
\hline Heptanoic acid & RI, MS & ND & 1,091 \\
\hline Nonanal & RI, MS & ND & 1,104 \\
\hline Maltol & RI, O, MS & Cooked, sweet & 1,109 \\
\hline Octanoic acid & RI, MS & ND & 1,184 \\
\hline Decanal & RI, O, MS & Soapy & 1,206 \\
\hline o-Aminoacetophenone & RI, O, MS & Tortilla, corn chip & 1,318 \\
\hline Decanoic acid & RI, MS & ND & 1,381 \\
\hline Vanillin & RI, MS & ND & 1,393 \\
\hline$\delta$-Decalactone & RI, O, MS & Sweet & 1,491 \\
\hline Dodecanoic acid & RI, MS & ND & 1,566 \\
\hline$\delta$-Dodecalactone & RI, MS & ND & 1,702 \\
\hline
\end{tabular}

${ }^{1} \mathrm{RI}=$ retention index; $\mathrm{O}=$ odor; $\mathrm{MS}=$ mass spectra; $\mathrm{ND}=$ odor not detected (not aroma active).

could be more pronounced because the flavor intensity in the condensed milk is significantly decreased, thus small changes in cardboard flavor could be perceived when they are not perceived when sweet aromatic flavor intensity is higher.

The effect of liquid storage was similar to that of the method of concentration to $30 \%$ solids. Storage of liquid condensed milk decreased sweet aromatic flavor and increased cardboard flavor. Decreases in the same characteristic milk flavor compounds were also observed as stated with the effect of $\mathrm{E}$ versus RO. In contrast to the effect of the method of concentration, storage of condensed milk increased the concentrations of the lipid oxidation compounds hexanal and octanal, indicating that lipid oxidation did occur during $24 \mathrm{~h}$ of storage. The combined effect of a decrease in the potential suppression of sweet aromatic flavor on cardboard flavor and the increase in lipid oxidation compounds is most likely the cause of the increase in cardboard flavor intensity due to liquid storage. Liquid storage also affects the flavor of liquid whey and whey protein ingredients. Storage of liquid whey (sweet or acid, cultured and uncultured), liquid whey protein concentrate $80 \%$ and liquid whey protein isolate increased cardboard flavor and lipid oxidation compounds in spraydried whey protein concentrate $80 \%$ and whey protein isolate(Whitson et al., 2011; Park et al., 2016; Smith et al., 2016).
The FUR results demonstrate that $\mathrm{E}$ does heat the product more than $\mathrm{RO}$ and that Maillard reaction products were increased. In our study, the FUR values of RO NFDM decreased by $28.7 \%$ (41.6 vs. $30.9 \mathrm{mg}$ FUR/100 g of protein) compared with E NFDM. Because RO did not have any heat applied to it, the FUR from the RO NFDM must have come from pasteurization, E concentration from 30 to $50 \%$ solids, spray drying, or a combination of these. It can be concluded, however, that in our case approximately $30 \%$ of the total FUR from the E NFDM was produced during E to $30 \%$ solids. Future work should investigate the role of spray-drying parameters on FUR concentrations in NFDM. Furosine is an indicator of the Maillard reaction and can be used to measure blocked lysine, leading to decreased digestibility of the protein in the milk powder (Erbersdobler and Somoza, 2007; Mehta and Deeth, 2015). Using the formula given by Mehta and Deeth (2015), the percentage of blocked lysine at 41 $\mathrm{mg}$ of FUR/100 $\mathrm{g}$ of protein is 1.39\%. Lysine blockage in low-heat NFDM that we produced is therefore very minimal, but in medium and high heat powders it could be much more significant. Van Renterghem and De Block (1996) reported values for freshly prepared lowheat NFDM between 100 and $120 \mathrm{mg}$ of FUR/100 g of protein. These differences could be due to temperatures and hold times used during pasteurization, preheating, E, and spray drying. 
Previous studies have investigated how spray-drying parameters affect the powder particle size of milk powders and whey protein concentrate (Nijdam and Langrish, 2006; Kim et al., 2009; Park et al., 2014). In general, increased feed solids concentration and inlet temperature increase the powder particle size of dried dairy ingredients. To our knowledge, the effect of condensed milk storage and method of concentration on powder particle size in NFDM has not been investigated before our study. Bienvenue et al. (2003) demonstrated that $4 \mathrm{~h}$ of storage of condensed skim milk (45\% solids) at $50^{\circ} \mathrm{C}$ significantly increased the viscosity. There could be a slight increase in viscosity with $24 \mathrm{~h}$ storage of $\mathrm{E}$ condensed milk due to protein aggregation that occurred during evaporation due to the heat applied. Jinapong et al. (2008) observed a positive correlation between feed viscosity entering the spray dryer and particle size of instant soymilk powders. In addition, larger casein micelles during spray drying could lead to larger powder particle size even if viscosity is similar. Bienvenue et al. (2003) observed that the particle size of protein aggregates condensed skim milk (45\% solids) increased dramatically during $8 \mathrm{~h}$ of storage at $50^{\circ} \mathrm{C}$. This increase was irreversible. They hypothesized that the casein micelles either fused or aggregated together, forming much larger protein aggregates. In our experiment, casein micelle aggregation could have initiated in the condensed milk with $\mathrm{E}$ due to the heat involved and increased during storage. A decrease in $\mathrm{pH}$ with increased temperature has been observed in skim milk (Chaplin and Lyster, 1988; Anema, 2009). The pH values of $30 \%$ solids condensed milk at $63^{\circ} \mathrm{C}$ (E processing temperature) and $18^{\circ} \mathrm{C}$ ( $\mathrm{RO}$ processing temperature) were 6.25 and 6.48 , respectively. Because the RO condensed milk was not heated during concentration, aggregation of casein micelles would have been hindered and the effect of storage on powder particle size of the NFDM would not be the same as we observed.

The increase in $\mathrm{D}[4,3]$ from $\mathrm{E} 0 \mathrm{~h}$ and $\mathrm{E} 24 \mathrm{~h}$ constituted a $25 \%$ increase, whereas the decrease in $\mathrm{D}[4,3]$ from RO $0 \mathrm{~h}$ and RO $24 \mathrm{~h}$ constituted a $20 \%$ decrease. Park et al. (2014) observed a decrease in cardboard flavor with an increase in powder particle size in whey protein concentrate $80 \%$. They hypothesized that the reason for this was decreased SFF with increased powder particle size, which decreased lipid oxidation. We did not observe differences in SFF even though powder particle size was different and that may be attributed to the fact that the total fat content in the NFDM was very low $(0.743 \%)$. It could also be due to the fact that the greatest difference in $\mathrm{D}[4,3]$ among the treatments they observed was approximately $100 \%$, whereas our greatest difference was only about $20 \%$. We hypothesize that we did not see this same trend due to the smaller difference in powder particle size, the lower fat content, and other confounding variables such as unit operation differences and liquid storage.

Although we did not observe differences in SFF along with the powder particle size in NFDM, they could be used as indicators of drying conditions. Future work should attempt to link spray-drying conditions to the flavor and shelf-life of NFDM. Also, because our work demonstrates that powder particle size of NFDM is affected by unit operations, future work should investigate how these unit operations influence the functional properties of NFDM and other dried dairy ingredients.

\section{CONCLUSIONS}

Unit operations during the manufacture of NFDM affect NFDM flavor. Use of RO to concentrate to $30 \%$ solids decreased cardboard off-flavor and increased sweet aromatic flavor of NFDM compared with E concentration to $30 \%$ solids. To mitigate off-flavors, storage of condensed milk should be avoided because it increased cardboard off-flavor and decreased sweet aromatic flavor. We demonstrated that the cause of off-flavors in NFDM was a combination of heat and vacuum during $\mathrm{E}$ due to the removed characteristic milk flavor compounds. These results demonstrate to milk powder manufacturers that $\mathrm{RO}$ should be used as much as possible during milk concentration and liquid storage should be avoided where possible.

\section{ACKNOWLEDGMENTS}

The authors express gratitude to Dave Barbano and his group (Cornell University, Ithaca, NY) for performing the Kjeldahl analyses. Funding was provided in part by the National Dairy Council (Rosemont, IL). The use of tradenames does not indicate endorsement or indicate a lack of endorsement by those not mentioned.

\section{REFERENCES}

ADPI. 2002. Standards for grades of dry milks including methods of analysis. 2nd ed. American Dairy Products Association, Elmhurst, IL.

ADPI. 2015. Skim milk powder. Accessed Apr. 30, 2015. https://www. adpi.org/DairyProducts/DryMilks/SkimMilkPowder/tabid/359/ Default.aspx.

Anema, S. G. 2009. Effect of milk solids concentration on the $\mathrm{pH}$, soluble calcium and soluble phosphate levels of milk during heating. Dairy Sci. Technol. 89:501-510.

AOAC International. 2000. Official Methods of Analysis. 17th ed. AOAC International, Gaithersburg, MD.

Augustin, M. A., L. J. Cheng, and P. T. Clarke. 1999. Effects of preheat treatment of milk powder on the properties of reconstituted set skim yogurts. Int. Dairy J. 9:415-416.

Bienvenue, A., R. Jimenez-Flores, and H. Singh. 2003. Rheological properties of concentration skim milk: Importance of soluble 
minerals in the changes in viscosity during storage. J. Dairy Sci. $86: 3813-3821$.

Carunchia Whetstine, M. E., A. E. Croissant, and M. A. Drake. 2005. Characterization of dried whey protein concentrate and isolate flavor. J. Dairy Sci. 88:3826-3839.

Caudle, A. D., Y. Yoon, and M. A. Drake. 2005. Influence of flavor variability in skim milk powder on consumer acceptability of ingredient applications. J. Food Sci. 70:S427-S431.

Chaplin, L. C., and R. L. J. Lyster. 1988. Short communication: Effect of temperature on the $\mathrm{pH}$ of skim milk. J. Dairy Res. 55:277-280.

Drake, M. A., Y. Karagul-Yuceer, K. R. Cadwallader, G. V. Civille, and P. S. Tong. 2003. Determination of the sensory attributes of dried milk powders and dairy ingredients. J. Sens. Stud. 18:199216

Drake, M. A., R. E. Miracle, A. D. Caudle, and K. R. Cadwallader. 2007. Relating sensory and instrumental analyses. Pages 23-55 in Sensory-Directed Flavor Analysis. R. Marsili, ed. CRC Press, Boca Raton, FL.

Erbersdobler, H. F., and V. Somoza. 2007. Forty years of furosineForty years of using Maillard reaction products as indicators of the nutritional quality foods. Mol. Nutr. Food Res. 51:423-430.

GEA. 2005. Surface free fat of powder-method 10a. GEA Niro analytical methods. GEA Niro, Soeborg, Denmark.

Isleten, M., and Y. Karagul-Yuceer. 2006. Effects of dried dairy ingredients on physical and sensory properties of nonfat yogurt. J. Dairy Sci. 89:2865-2872.

Jinapong, N., M. Suphantharika, and P. Jamnong. 2008. Production of instant soymilk powders by ultrafiltration, spray drying and fluidized bed agglomeration. J. Food Eng. 84:194-205.

Karagul-Yuceer, Y., K. R. Cadwallader, and M. A. Drake. 2002. Volatile flavor components of stored nonfat dry milk. J. Agric. Food Chem. 50:305-312.

Karagul-Yuceer, Y., M. A. Drake, and K. R. Cadwallader. 2001. Aroma-active components of nonfat dry milk. J. Agric. Food Chem. 49:2948-2953.

Karagul-Yuceer, Y., M. A. Drake, and K. R. Cadwallader. 2004. Evaluation of the character impact odorants in skim milk powder by sensory studies on model mixtures. J. Sens. Stud. 19:1-13.

Kim, E. H. J., X. D. Chen, and D. Pearce. 2009. Surface composition of industrial spray-dried milk powders. 2. Effects of spray drying conditions on the surface composition. J. Food Eng. 94:169-181.

Lloyd, M. A., M. A. Drake, and P. D. Gerard. 2009b. Flavor variability and flavor stability of U.S.-produced whole milk powder. J. Food Sci. 74:S334-S343

Lloyd, M. A. S. J. Hess, and M. A. Drake. 2009a. Effect of nitrogen flushing and storage temperature on flavor and shelf-life of whole milk powder. J. Dairy Sci. 92:2409-2422.

Mehta, B. M., and H. C. Deeth. 2015. Blocked lysine in dairy products: Formation, occurrence, analysis, and nutritional implications. Compr. Rev. Food Sci. Food Saf. 15:206-218.
Meilgaard, M. C., B. T. Carr, and G. V. Civille. 2009. Sensory Evaluation Techniques. 4th ed. CRC Press, Boca Raton, FL.

Nijdam, J. J., and T. A. G. Langrish. 2006. The effect of surface composition on the functional properties of milk powders. J. Food Eng. 77:919-925.

NIST (National Institute of Standards and Technology). 2014. NIST 14 mass spectral library. FarHawk Marketing Services, Evans Mills, NY.

Oldfield, D. J., M. W. Taylor, and H. Singh. 2005. Effect of preheating and other process parameters on whey protein reactions during skim milk powder manufacture. Int. Dairy J. 15:501-511.

Park, C. W., E. Bastian, B. Farkas, and M. A. Drake. 2014. The effect of feed solids concentration and inlet temperature on the flavor of whey protein concentrate. J. Food Sci. 79:C19-C24.

Park, C. W., M. N. Parker, and M. A. Drake. 2016. The effect of liquid storage on the flavor of whey protein concentrate. J. Dairy Sci. 99:4303-4308.

Pischetsrieder, M., U. Grob, and C. Schoetter. 1999. Detection of Maillard products of lactose in heated or processing milk by HPLC/ DAD. Z. Lebensm. Unters. Forsch. 208:172-177.

Prieto, A., O. Basauri, R. Rodil, A. Usobiaga, L. A. Fernandez, N. Etxebarria, and O. Zuloaga. 2010. Stir-bar sorptive extraction: A view on method optimization, novel applications, limitations and potential solutions. J. Chromatogr. A 1217:2642-2666.

Resmini, P., L. Pellegrino, and G. Battelli. 1990. Accurate quantification of furosine in milk and dairy products by a direct HPLC method. Ital. J. Food Sci. 2:173-183.

Shiratsuchi, H., Y. Yoshimura, M. Shimoda, K. Noda, and Y. Osajima. 1995. Contributors to sweet and milky odor attributes of spraydried skim milk powder. J. Agric. Food Chem. 43:2453-2457.

Smith, S., T. J. Smith, and M. A. Drake. 2016. Flavor and flavor stability of cheese, rennet, and acid wheys. J. Dairy Sci. 99:3434-3444.

Stabile, R. L. 1983. Economics of reverse osmosis and multistage evaporation for concentrating skim milk from 8.8 to $45 \%$ solids. J. Dairy Sci. 66:1765-1772.

Stapelfeldt, H., B. R. Nielsen, and L. H. Skibsted. 1997. Effect of heat treatment, water activity and storage temperature on the oxidative stability of whole milk powder. Int. Dairy J. 7:331-339.

USDA. 2015. Dairy Products Summary. Accessed Apr. 13. 2015. http:// usda.mannlib.cornell.edu/usda/nass/DairProdSu//2010s/2015/ DairProdSu-04-29-2015.pdf.

Van Renterghem, R., and J. De Block. 1996. Furosine in consumption milk and milk powders. Int. Dairy J. 6:371-382.

Whitson, M. E., R. E. Miracle, E. Bastian, and M. A. Drake. 2011. Effect of liquid storage on flavor of spray dried whey protein concentrate and isolate. J. Dairy Sci. 94:3747-3760.

Whitson, M. E., R. E. Miracle, and M. A. Drake. 2010. Sensory characterization of chemical components responsible for cardboard flavor in whey protein. J. Sens. Stud. 25:616-636. 